\title{
Ideological externalities, social pressures, and political parties
}

\author{
Amihai Glazer
}

Received: 13 November 2008 / Accepted: 8 August 2009 / Published online: 1 September 2009

(c) The Author(s) 2009. This article is published with open access at Springerlink.com

\begin{abstract}
Members of political parties may influence each other. For example, a liberal in a party of moderates may moderate his views. At the same time, the moderates in the party may become more liberal. Voters in a district who favor such effects may care about the ideology of officeholders in other districts. They may therefore prefer a candidate who affiliates with a party over an independent with the same position.
\end{abstract}

Keywords Elections $\cdot$ Parties $\cdot$ Social networks

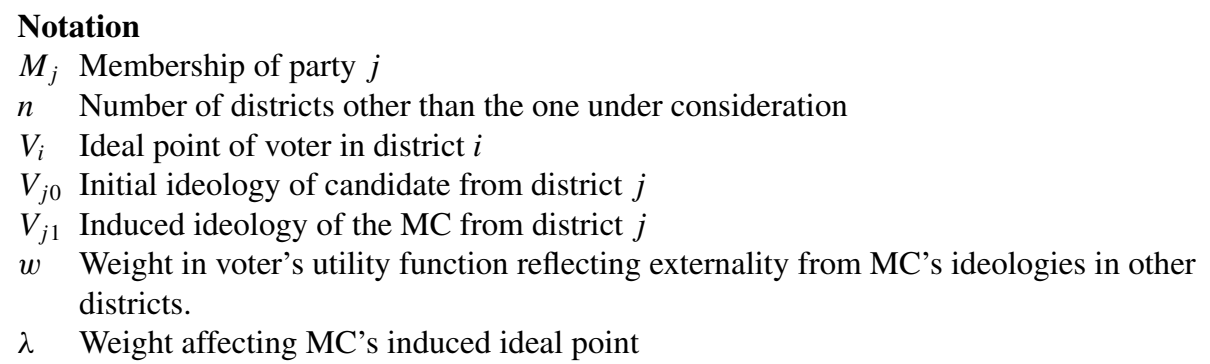

\section{Introduction}

This paper uses ideas from social networks to explain why voters may prefer a candidate who joins some political party over an otherwise identical candidate who joins a different party or no party. It considers a political party as a social organization, with its members influencing each other. A voter may dislike having the district's representative swayed by the views of other party members. But a voter may want representatives from other districts

I am grateful to a referee and to the associate editor for comments which allowed me to improve the paper.

\footnotetext{
A. Glazer $(\bowtie)$

Department of Economics, University of California, Irvine, CA 92697, USA

e-mail: aglazer@uci.edu
} 
to move closer to the voter's ideology. The balance of these two opposing effects can make a voter prefer a representative who joins a party. The paper makes several contributions. First, it shows how a candidate can win votes by joining a party. Second, the analysis has membership in parties endogenous - a candidate will join the party that maximizes his popularity within his constituency. Third, it allows the parties to form endogenously. In particular, rather than taking the ideology of parties as given, the paper shows that in equilibrium two parties may form, one on the left and one on the right. Fourth, following Krehbiel (1993), the analysis allows a political party to influence behavior, rather than merely to agglomerate like-minded officials.

Of course, many other papers, including those surveyed below, consider the electoral benefits of political parties. Some, but not all, of these explanations satisfy an important criterion formulated by Krehbiel (1993). He notes that legislators who share preferences or other motivating factors will naturally show voting patterns that appear consistent with party behavior, independent of the party's existence. Thus, it is important to distinguish "partylike" behavior from changes in behavior caused by parties. My approach does this.

\section{Literature}

Others have studied the electoral benefits to a candidate of joining a political party. One approach emphasizes that a political party can commit to future policy. ${ }^{1}$ Others see parties as long-run players that discipline candidates with short horizons. Alesina and Spear (1988) model a political party as an infinite sequence of overlapping generations of finitely-lived politicians; they describe a transfer scheme between a candidate and the party which allows a party's current and future candidates to commit to a moderate platform and thereby to increase electoral success. Harrington (1992) demonstrates how explicit commitment is unnecessary: a trigger strategy can allow parties to sustain moderate platforms.

The benefits of party formation in a legislative bargaining game are modeled by Jackson and Moselle (2002): if legislators propose policies in random order, then legislators who bind themselves to make proposals that benefit each other will enjoy higher expected utility than when each acts independently.

A different approach emphasizes how party membership informs voters. Thus, Snyder and Ting (2002) view a candidate as inclined to join a party with members whose positions are similar to his. Party membership then informs voters of the candidate's positions, and therefore with risk-averse voters increases his electoral popularity. Caillaud and Tirole (2002) interpret parties as information intermediaries that select high-quality candidates.

\subsection{Peer-group effects}

Experimental evidence shows strong social influences on individual judgment (e.g., Sherif 1935; Festinger et al. 1950; and Asch 1951). A fine survey of this literature is Marsden and Friedkin (1993). Data also show the existence of social influences on the behavior of politicians. Fenno (1978) speaks of a legislator's personal constituency, which includes fellow legislators, as influencing him. Several authors examine friendship among legislators, finding that a legislator is especially likely to befriend legislators of the same party, and that friends are more likely to vote the same way on roll-calls. In a study of 93 members of the

\footnotetext{
${ }^{1}$ For example, Levy (2000) and Baron (1993) assume parties are constrained in their platforms, thereby increasing their power when they bargain over forming a coalition.
} 
Ohio State Legislature in 1993, Arnold et al. (2000) find that friendship increased shared voting, even after controlling for party and shared ideology. ${ }^{2}$ In the early 19 th century, fraternities of congressmen nested in boardinghouses functioned as voting blocs; patterns of roll-call voting reflected the social networks derived from congressmen's social lives (Young 1966).

In the four legislatures Wahlke et al. (1962) study, members sought friendships within their own parties. And legislators who chose each other as friends tended to agree on roll calls. In the California Assembly, legislators who happen to be assigned seats next to each other tend to vote alike (Masket 2008). In the Iowa legislature, shared partisanship increases friendship (Caldeira and Patterson 1987). More generally, a person's beliefs can depend on the beliefs of others (Kuran 1995), and preferences may be endogenous (Becker and Murphy 1988). Friedkin (2003) formulates a social networks model of mutual influences, and describes experimental evidence supporting it. The ideas are applied to politics by Shleifer and Murphy (2004), who consider networks with mutual influences among their members. Like them, I find that in equilibrium political platforms can diverge, but unlike them I show how an individual politician benefits from joining a party.

Aldrich (1983a, 1983b) sees party activists as concerned about the ideological stance of the party, and supposes that voters who find that the location of one party's activists are closer to their own preferences than that of the other party may become activists themselves. That in turn moves the location of the average party member in the direction of the new activist, which further affects who will join the party. The aggregation of the decisions of party activists may thus generate stable equilibria in which the two parties have different ideologies. My model also examines endogenous choice of which party to join. But whereas Aldrich views each party member as atomistic, I allow a legislator to consider how his own partisan choice affects the ideologies of other legislators.

\section{Assumptions}

I shall consider elected officials who benefit from joining a party because of the influence of party membership on other party members. For convenience, I speak of voters and candidates, with each candidate aiming to maximize his popularity with his district's voters, and therefore joining the party the voters prefer he join. Similar analysis applies under a citizencandidate model, ${ }^{3}$ in which an elected official maximizes his own utility. The more detailed assumptions are given below.

\subsection{Voters}

A voter's preferences are single-peaked over a one-dimensional policy. ${ }^{4}$ For simplicity, voters within a district are identical. Voters support the candidate whose position will maximize the utility of voters in his district.

\footnotetext{
${ }^{2}$ The authors' findings are, however, consistent with the reverse causality-legislators befriend others with similar political preferences.

${ }^{3}$ See Besley and Coate (1997).

${ }^{4}$ This assumption simplifies the exposition. Under the citizen-candidate model, where an elected official maximizes his own utility, the analysis could be extended to multiple dimensions.
} 


\subsection{Cross-district externalities}

Voters in one district may care about the ideologies of Members of Congress (MCs) in other districts. Name by $P$ the MC under consideration. Consider the Downsian model, where the legislator with an ideal point at the median casts the decisive vote. Then voters in any district want to move the preferences of the median legislator in their direction. Or they want to move the preferences of a legislator who is not at the median so as to change the identity of the median legislator, and thus change policy in a direction they desire. Relatedly, because of a committee's power, policy may be set by members of a committee on which $P$ does not sit. Or perhaps districts generate externalities on each other (say from pollution) and so need MCs who see each other often or who understand each other. Membership in the same party promotes that.

Assume therefore that a voter's utility depends on the induced preferences of $P$ and of other MCs, though the voter may care more about $P$. More specifically, let the number of MCs be $n+1$. Let $w>0$ be a parameter indicating the weight a voter places on the gap in ideologies between $P$ and other MCs. Indicate by $V_{k}$ the ideal point of each voter in district $k$; the induced ideology of the MC from district $j$ is $V_{j 1}$. Then the utility of a voter in district $k$ is

$$
U_{k}=\left(V_{k}-V_{k 1}\right)^{2}+w \sum_{j \neq k}\left|V_{k}-V_{j 1}\right| .
$$

Voters may not recognize how their congressman influences another. That is, they may care about how a congressman is influenced, but not how he influences others. But the results of the analysis below would also hold if candidates are at least partly policy-oriented, cannot commit to not joining a party, and if after an election an incumbent decides to join a party. The example in 2009 of Senator Arlen Specter of Pennsylvania switching from the Republican to the Democratic party may demonstrate this effect at work. The switch could moderate other Democrats, to the benefit of Senator Specter.

\subsection{Candidates}

Each candidate, say $i$, has an innate ideal point, $V_{i 0}$. For simplicity, the issue space is onedimensional. The members of party $j$ are indicated by $j \in M_{j}$; the number of members is $n_{j}$. A candidate can commit to join a particular party; the only effect of party membership is to create mutual influences among its members.

Candidate $i$ with initial ideal point at $V_{i 0}$ who belongs to party $j$ has induced ideal point $V_{i 1} \equiv \lambda V_{i 0}+(1-\lambda) \sum_{k \in M_{j}} V_{k 0} / n_{j}$. This formulation, which makes induced ideology a weighted average of initial ideology and of the ideologies of other party members, closely follows the formulation used by sociologists in Social Network Influence Theory (see Friedkin 2003). ${ }^{5}$ A candidate joins whichever party will generate a set of induced positions for all MCs which best appeals to the voters in the MC's district.

\section{Equilibria}

Several propositions give sufficient conditions for voters to prefer that a candidate join a political party rather than work independently.

\footnotetext{
${ }^{5}$ The model can be generalized by making $\lambda$ a function of $n_{j}$ and of the distances between the ideal points of the MCs. This generalization would allow, for example, for stronger influences within a small group than within a large group.
} 
Proposition 1 If other party members little influence a member's ideology, then voters would prefer that $P$ join a party over his working alone.

Explanation: If a legislator's membership in a party generates only small movements in his ideology, the voters in a district are certain to benefit from his joining a party. A small move away from a voter's ideal point has a second-order effect on that voter's utility. But a small move in another district has a first-order effect on the voter's utility.

Proposition 2 As a corollary, $P$ benefits from joining a party which will little affect his ideology. For example, an incumbent's ideology may change little when joining a party whose mean ideology lies close to the incumbent's.

Proposition 3 If P little cares about his own ideology, but cares about the induced ideologies of others, then he benefits from joining a party.

Explanation: By joining a party, $P$ affects the ideology of other party members, which increases his utility. The change in his own ideology, since it stays near his optimum, little reduces his utility.

So far I discussed a legislator' decision about joining a party. I can also study the preferences of party members to accept a legislator to their party.

Proposition 4 If each party member suffers increasing marginal disutility from the ideology of other members, then party members will favor a moderate joining the party.

Explanation: Consider an extreme leftist, say $P$, in the party. A moderate who joins the party moves the leftists and rightists in the party towards the middle. The loss in utility to $P$ from a rightward movement of leftists is less than $P$ 's gain in utility from the leftward movement of rightists.

Proposition 5 Current party members will oppose the membership of an extremist within that party.

Explanation: Again, assuming increasing marginal disutility, an extremist moves the induced ideology to an extreme, say to the right. The gain to rightists is less than the loss to leftists within the party.

The result that a voter in a district would benefit from $P$ joining a party consisting of MCs with initial ideal points sufficiently close to the voter's immediately suggests how parties may form. A liberal voter gains from $P$ joining a party of liberals, and a conservative voter gains from $P$ joining a conservative party. Moreover, a liberal voter who suffers large disutility whenever $P$ moves far from the voter's ideal point would oppose a $P$ who intends to join the conservative party. In short, when the distribution of voters' ideologies is bimodal, an equilibrium can have two parties.

Centrists in a party gain the most from joining a party. They gain from changing the positions of other MCs toward the center in the party. But they suffer little from their own ideological change: centrists are pulled in opposite directions, and so their induced ideology is close to their initial ideology. Such incentives could lead to the formation of a party composed of centrists, with MCs at the extremes joining no party. 


\subsection{Ideological parties}

More challenging is showing that with an even distribution of preferences the equilibrium can have two, ideologically distinct, parties. To see how this separation can arise, let the ideal points of the $10 \mathrm{MCs}$ lie at $1,2, \ldots, 10$, with lower indices representing more liberal views. I will verify the existence of a Nash equilibrium in which MCs $1, \ldots, 5$ constitute one party ("Democrats") and MCs $6, \ldots, 10$ constitute the other party ("Republicans").

Notice that voters in a district who care much about the ideology of MCs in other districts may want $P$ to join a party whose members have ideologies far different from the ideal point of voters in the district. In particular, with quadratic disutility from the ideology of a different $\mathrm{MC}$, voters in a district may be desperate to move the ideology of MCs in other districts. To avoid such behavior, which appears rare, assume that disutility from deviation by $P$ is quadratic, but that the disutility from the ideology of other MCs is linear.

At an equilibrium with the two parties, the induced ideology of a Democrat with initial ideology $i$ is

$$
V_{D}^{5 D R R}(i)=\lambda i+(1-\lambda)\left(-i+\sum_{j=1}^{5} j\right) / 4
$$

The induced ideology of a Republican with initial ideology $i$ is

$$
V_{R}^{5 D 5 R}(i)=\lambda i+(1-\lambda)\left(-i+\sum_{j=6}^{10} j\right) / 4
$$

The utility of a voter in district $k$ (for $k=1, \ldots, 5$ ) when MCs $1, \ldots, 5$ are Democrats, and MCs $6, \ldots, 10$ are Republicans, is

$$
\begin{aligned}
U_{D}^{5 D R}(k)= & -\left(v_{D}^{5 D 5 R}(k)-k\right)^{2}-w \sum_{i=1}^{5}\left|V_{D}^{5 D 5 R}(i)-k\right|+w\left|V_{D}^{5 D 5 R}(k)-k\right| \\
& -w \sum_{i=6}^{10}\left|V_{R}^{5 D 5 R}(i)-k\right| .
\end{aligned}
$$

To check for a Nash equilibrium we must consider the two options for an MC who is initially a party member. The MC can join the other party, or can work as an independent (joining neither party). Either way, the Democratic party will consist of four members instead of five. The ideology of a Democratic party member $i$ when MC $k$ no longer belongs to the Democratic party is

$$
V_{D}^{4 D 6 R}(i, k)=\lambda i+(1-\lambda) \frac{\left(\sum_{i=1}^{5} j\right)-i-k}{3} .
$$


The utility of a voter in district $i=1, \ldots, 5$ when $P$ is an independent is therefore ${ }^{6}$

$$
U_{0}^{4 D 5 R}(k)=-w \sum_{i=1}^{5}\left|V_{D}^{4 D 6 R}(i, k)-k\right|+w\left|V_{D}^{4 D 6 R}(k, k)-k\right|-w \sum_{i=6}^{10}\left|V_{R}^{4 D 5 R}(i)-k\right| .
$$

Lastly, consider an MC who was initially in the Democratic party but moves to the Republican party. The induced ideology of this MC, $k$, becomes

$$
V_{R}^{4 D 6 R}(k)=\lambda k+(1-\lambda)\left(\sum_{j=6}^{10} j\right) / 5 .
$$

Now that MC $k$ is a Republican, the ideology of Republican MC $i$ is

$$
V_{R}^{4 D 6 R}(i)=\lambda i+(1-\lambda)\left(k-i+\sum_{j=6}^{10} j\right) / 5 .
$$

The utility of a voter in district $k$, with an MC who is now a Republican, is

$$
\begin{aligned}
U_{R}^{4 D 6 R}(k)= & -\left(v_{R}^{4 D 6 R}(k, k)-k\right)^{2}-w \sum_{i=1}^{5}\left|V_{D}^{4 D 6 R}(i, k)-k\right| \\
& +w\left|V_{D}^{4 D 6 R}(k, k)-k\right|-w \sum_{i=6}^{10}\left|V_{R}^{4 D 6 R}(i)-k\right| .
\end{aligned}
$$

The conditions for two symmetric parties to exist in equilibrium are that each member prefers to belong to his party than to work alone, and that none wants to join the other party. For a member of the Democratic party, these conditions are $U_{D}^{5 D 5 R}(k)>U_{0}^{4 D 5 R}(k)$ and $U_{D}^{5 D 5 R}(k)>U_{R}^{4 D 6 R}(k)$.

These conditions need not always hold. Thus, for $\lambda=1 / 2$ and values of $w$ which make the MC with ideal point at 5 satisfied with membership in the Democratic party, the MC with ideal point at 1 would gain from joining the Republican party - the MC would thereby shift the induced ideal points of the Republicans sufficiently far to the left as to outweigh his own shift to the right.

But a separating equilibrium can exist. Suppose $\lambda=95 / 100$, and $0.125<w<1.53$. Then the equilibrium can consist of one party on the left and one on the right, though districts are evenly distributed along the ideological spectrum.

\subsection{Strategic voting}

Voters who care much about the preferences of MCs in other districts may gain from electing an extremist, who will cause the other members of the party to evolve toward $P$ 's positions. That is, liberal voters may vote for extreme liberals. This result contrasts with the standard

\footnotetext{
${ }^{6}$ I assume for simplicity that an independent, a loner, influences no one. That is an extreme assumption. A less extreme assumption has voters uncertain about an independent's colleagues, so that voters poorly predict the mutual influences, and believe that on average the independent's induced ideology is close to his initial ideology.
} 
Downsian model-if the liberal is to the left of the median, then it does not matter how liberal he is. And my approach can generate results that may look like expressive voting. ${ }^{7}$

There is an additional complication. Suppose MCs $A$ and $B$ belong to the same party, so that each moves his ideology toward $(A+B) / 2$. If this point is a permanent position, then voters in district $A$ may gain from replacing the incumbent with someone whose ideal point is at $A$ rather than toward $(A+B) / 2$. On the other hand, an old-time incumbent may exert more influence, moving other MCs toward his position. And so voters will re-elect incumbents.

\section{Implications}

The approach adopted here can be extended in several directions. First, the mechanism can apply beyond political parties; it can also apply to membership on congressional committees: voters in a district may want their congressman to join a committee because he can thereby affect the ideologies of other members of the committee.

Second, my model predicts that an MC will avoid joining a party or a coalition consisting of ideologically rigid members-socializing with them will not change their opinions. Maybe that is why the Communists were rarely accepted into coalitions.

Third, a voter's concern about the ideology of MCs in other districts will be greater the more likely the voter is to move, and the greater the political power of MCs from other districts. The evidence on this is mixed. In the United States the vote shares of third parties (such as Greenbacks, Populists, Progressives, and Prohibitionists) were more than double their shares than now. More than five times as many third-party congressmen were elected to the U.S. House of Representatives in 1890 to 1920 than in 1940 to 1970 (Hirano and Snyder 2007). Comparative data on residential mobility are hard to find. But Ferrie (2005) suggests that mobility was higher in 1890-1920 than in more recent years, which is not consistent with mobility reducing support for multiple parties. On the other hand, a voter will be more concerned about influencing the views of MCs from other districts when the federal government centralizes power than when local governments exert much control. Chhibber and Kollman (1998), examining India and the United States, indeed find that periods with few national parties correspond to periods of centralization.

Fourth, members of a party may prefer not to join a coalition which would force them to interact with members of other parties. For example, in 1924 Leon Blum and his Socialist party in France supported the Radical government of Edouard Herriot, but refused to become members of the cabinet. A similar pattern appeared in India following the 2004 elections: the Left Front did not accept cabinet posts, but agreed not to vote against the new government. In Israel, some members of the Agudat Israel party pursued a policy of non-contact with Zionists, seeing in them a threat to religious purity. So though the party supported various coalitions, it refrained from assuming cabinet positions (Arian 2005, pp. 151-152). These examples are not unique: minority cabinets account for about $35 \%$ of all governments in 15 parliamentary democracies from 1945 to 1982 (Strom 1984). In California budget negotiations of 2008, the Republican legislative leaders who negotiated with the Democrats were ousted by Republican legislators, consistent with the idea that party members preferred that

\footnotetext{
${ }^{7}$ Expressive voting builds on the idea that an individual who realizes that his vote will not decide the election may instead vote as an act of expressive behavior, and so can support a candidate whose policies the voter would not want implemented. For a discussion of expressive voting, see Schuessler (2000).
} 
leaders not associate with Democrats. Such reluctance to join a coalition appears to contradict standard assumptions-politicians seek power, whether for its own sake or to influence policy. But the behavior can make sense under my approach. The party members outside the cabinet may fear that the members who do join the cabinet will change their preferences.

Fifth, risk aversion and uncertainty about an MC's ideology can also lead voters to favor candidates who commit to joining a party. To see this, suppose voters in $n+1$ districts have the same ideal point, say 0 . Let voters be uncertain about the initial ideal point of each candidate, with the distribution of a candidate's ideal point having mean 0 and variance $\sigma^{2}$. The mean initial ideology of other MCs is then normally distributed with mean 0 and variance $\sigma^{2} / n$. With a weight of $\lambda$ on own ideology in determining induced ideology, the expected value of induced ideology is 0 . The variance of induced ideology is $\lambda^{2} \sigma^{2}+(1-\lambda)^{2} \sigma^{2} / n$, which for $0<\lambda<1$ is necessarily less than $\sigma^{2}$. Party membership reduces variance, making a candidate more attractive to risk-averse voters.

\section{Conclusion}

In discussing how party membership changes a legislator's ideology, I argued that the concern by voters about ideology in other districts may make voters favor a candidate expected to join a party. But even if this incentive is secondary, my approach can prove useful. For suppose parties form for other reasons-commitment, signaling, cost sharing, and so on. The mutual ideological influences can then shape the composition of parties, and the incentives to join them. For example, the main incentive for a candidate to join a party may lie with the economic efficiencies it provides. But in deciding which party to join, the effects I highlight may be important. Relatedly, parties will better signal ideology if peer pressures strengthen the ideological coherence of the party.

Open Access This article is distributed under the terms of the Creative Commons Attribution Noncommercial License which permits any noncommercial use, distribution, and reproduction in any medium, provided the original author(s) and source are credited.

\section{References}

Aldrich, J. H. (1983a). A Downsian spatial model with party activism. American Political Science Review, 77(4), 974-990.

Aldrich, J. H. (1983b). A spatial model with party activists: Implications for electoral dynamics. Public Choice, 41(1), 63-100.

Alesina, A., \& Spear, S. (1988). An overlapping generations model of electoral competition. Journal of Public Economics, 37(3), 359-379.

Arian, A. (2005). Politics in Israel: The second republic (2nd ed.). Washington: CQ Press.

Arnold, L. W., Deen, R. E., \& Patterson, S. C. (2000). Friendship and votes: The impact of interpersonal ties on legislative decision making. State and Local Government Review, 32(2), 142-147.

Asch, S. (1951). Effects of group pressure upon the modification and distortion of judgment. In H. Guetzkow (Ed.), Groups, leadership, and men (pp. 177-196). Pittsburgh: Carnegie Press.

Baron, D. P. (1993). Government formation and endogenous parties. American Political Science Review, 87(1), 34-47.

Becker, G. S., \& Murphy, K. M. (1988). A theory of rational addiction. Journal of Political Economy, 96(4), $675-700$.

Besley, T., \& Coate, S. (1997). An economic model of representative democracy. Quarterly Journal of Economics, 112(1), 85-114.

Caillaud, B., \& Tirole, J. (2002). Parties as political intermediaries. Quarterly Journal of Economics, 117(4), 1453-1491. 
Caldeira, G. A., \& Patterson, S. C. (1987). Political friendship in the legislature. Journal of Politics, 49(4), 953-975.

Chhibber, P., \& Kollman, K. (1998). Party aggregation and the number of parties in India and the United States. American Political Science Review, 92(2), 329-342.

Fenno, R. M. Jr. (1978). Home style: House members in their districts. New York: Harper Collins.

Ferrie, J. P. (2005). The end of American exceptionalism? Mobility in the U.S. since 1850. Journal of Economic Perspectives, 19(3), 199-215.

Festinger, L., Schachter, S., \& Back, K. (1950). Social pressure in informal groups. New York: Harper.

Friedkin, N. (2003). Social network influence theory: Toward a science of strategic modification of interpersonal influence systems. In Board on Behavioral, Cognitive, and Sensory Sciences and Education (BCSSE), National Academy of Sciences. Dynamic social network modeling and analysis: workshop summary and papers (pp. 89-100).

Harrington, J. E. (1992). The role of party reputation in the formation of policy. Journal of Public Economics, 49(1), 107-121.

Hirano, S., \& Snyder, J. M. (2007). The decline of third-party voting in the United States. Journal of Politics, $69(1), 1-16$.

Jackson, M., \& Moselle, B. (2002). Coalition and party formation in a legislative voting game. Journal of Economic Theory, 103(1), 49-87.

Krehbiel, K. (1993). Where's the party? British Journal of Political Science, 23(2), 235-266.

Kuran, T. (1995). Private truths, public lies: The social consequences of preference falsification. Cambridge: Harvard University Press.

Levy, G. (2000). The role of parties and endogenous parties in multidimensional policy space. Mimeo, London School of Economics.

Marsden, P. V., \& Friedkin, N. E. (1993). Network studies of social influence. Sociological Methods and Research, 22(1), 127-151.

Masket, S. E. (2008). Where you sit is where you stand: The impact of seating proximity on legislative cue-taking. Quarterly Journal of Political Science, 3(3), 301-311.

Schuessler, A. A. (2000). A logic of expressive choice. Princeton: Princeton University Press.

Sherif, M. (1935). A study in some social factors in perception. Archives of Psychology, 187, 1-60.

Shleifer, A., \& Murphy, K. M. (2004). Persuasion in politics. American Economic Association Papers and Proceedings, 94(2), 435-439.

Snyder, J., \& Ting, M. (2002). An informational rationale for political parties. American Journal of Political Science, 46(1), 90-110.

Strom, K. (1984). Minority governments in parliamentary democracies: The rationality of nonwinning cabinet solutions. Comparative Political Studies, 17(2), 199-227.

Wahlke, J. C. et al. (1962). The legislative system: Explorations in legislative behavior. New York: Wiley.

Young, J. S. (1966). The Washington community, 1800-1828. New York: Columbia University Press. 